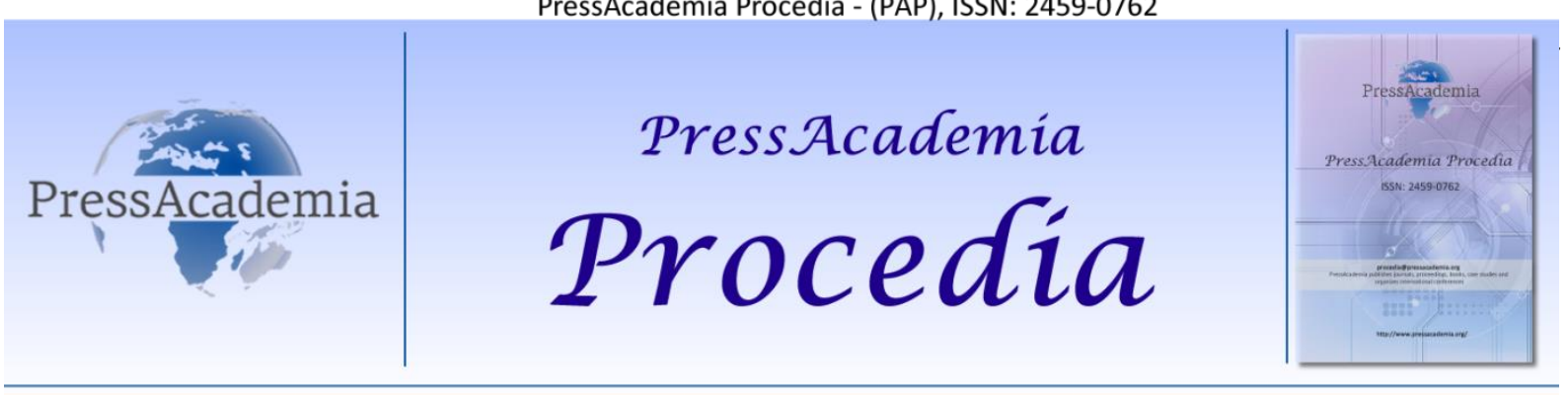

2nd World Conference on Technology, Innovation and Entrepreneurship

May 12-14, 2017, Istanbul, Turkey. Edited by Sefer Şener

\title{
REVIEW OF RISKS ASSOCIATED WITH RENOVATION \& MODERNIZATION OF THERMAL POWER PLANTS IN INDIA
}

\author{
DOI: 10.17261/Pressacademia.2017.586 \\ PAP-WCTIE-V.5-2017(24)-p.169-175
}

\author{
Purnima Bajpai ${ }^{1}$, K. Chandrashekhar Iyer $^{2}$ \\ ${ }^{1}$ The NorthCap University, Gurugram, Department of Civil Engineering, Indian Institute of Technology, Delhi. Purnima.bajpai.88@gmail.com \\ ${ }^{2}$ Department of Civil Engineering, Indian Institute of Technology, Delhi. kciyer@civil.iitd.ac.in
}

\begin{abstract}
Renovation and Modernization (R\&M) refers to a set of activities intended to improve the performance and reliability of the existing production facilities, and is seen as a cost-effective alternative to increase the operational life of plants. Through R\&M, obsolete generation equipment undergoes technological upgrades to boost capacity and reduce harmful emissions. It consists of a five-step process of identification, assessment, planning, execution and closure in order to plan, implement and monitor the entire procedure. The R\&M cost per Megawatt (MW) varies, depending on the age of plant, operational history, fuel type, demand of the equipment to be replaced, the cost of generation and technology. The study aims at of Renovation and Modernization R\&M of existing thermal power plants, which as an alternative can help the Country not only to increase the existing capacity and efficiency but will further help to reduce the heavy dependence on coal. Hence it is important to understand the major risks associated with the implementation of $R$ \& $M$ projects and mitigate them proactively to enhance the effectiveness of this approach.
\end{abstract}

Keywords: Risks, effectiveness, efficiency, renovation and modernization

\section{INTRODUCTION}

The main objective of Renovation \& Modernization ( $\& M)$ of plants is to make the existing units well equipped with modified technology, equipment's and systems, and further with an aim to improve and enhance their performance and efficiency purely in terms of the output generated, its reliability, adherence to the original design values and reduction in maintenance cost. Planning and implementing Renovation and Modernisation (R\&M) projects is often affected by occurrence of adverse events that can derail the objectives of the project. Identifying and mitigating project risks are crucial to successful management of R\&M projects. The major thermal power plants set up during the late nineties are facing the problems of declining efficiency. A power plant is said to be inefficient if the existing inputs are not utilized in an optimum manner and as a result of which its generation becomes lower than its maximum possible generation. With the high capital expenditure on new capacities, poor financial health of the utilities and emerging fuel constraints it is essential to maximize generation from the existing power stations by restoring their rated capacity and reduce the scarce fuel more efficiently. This calls for Renovation \& Modernisation (R\&M) of existing old power plants, which is one of the most cost effective option to achieve additional generation from existing old units at low cost in short time period.

In India, the thumb-rule for adding one Mega Watt of fresh generating capacity entails a capital expenditure of around $\$ 1$ million. However, an equivalent capacity can be achieved by investing almost one third of that amount on renovation and modernisation (R\&M). The cost of R\&M programmes are far less in comparison to new plant constructions and can be completed in a much shorter time compared to the gestation period of a new thermal power projects. R\&M is an efficiency improvement tool and can improve power generation by 30 per cent, environmental impact by 47 per cent and efficiency by 23 per cent. 


\section{LITERATURE REVIEW}

Based on the literature the key challenges impeding the market development mainly pertaining to the R\& $M$ division of power plants can be categorized into the following categories: Market challenges, Finance related challenges, Regulatory challenges, Operation and Maintenance (O \& M) issues, Contractual challenges, Institutional challenges, Implementation challenges. The major challenges for successful implementation of R\&M projects for different plants identified through the literature are as follows: Problems in defining the precise scope of work and defining the exact parameters that needs to be taken up, Uncertainty/deterioration in the phases between conducting the reduced life assessment studies as well as Condition assessment studies, award of the work and implementation of the projects, Limited number of agencies for ready to take up R\&M projects.

R\&M activity is to be fit together with the planned shutdown in order to ensure technology upgradation or extended life of the plant. On the other hand there are major encumbrances associated with the execution of the R \& M works; there are various uncertainties because of the difficulty in the estimation of the scope and type of work which is needed until these generating units are opened up after rehabilitation. Taking the power sector as the basis, some of the study some major challenges faced by the thermal power renovation and modernization shall be discussed in detail.

\subsection{Market Challenges}

Even though there is significant R\&M potential in India, the commercial opportunities within the market are limited. The actual achievement with respect to the planned R\&M during the 10th and 11th Plan has been only a mere $9 \%$ and $17 \%$ respectively. The utilities in India usually follow two drastically different models (nomination and tendering) to select the suppliers for undertaking the requisite R\&M works. The award of projects which is done generally on nomination basis to the existing $O \& M$ Contractors restrict the competition in the market and leads to a major barrier for various other suppliers. An analysis of the R\&M market in India indicates that out of the total R\&M capacity as per plan of 6501 MW which is almost equal to $31 \%$ ( $2030 \mathrm{MW}$ ) of the total capacity was awarded on nomination basis. It can also be seen from records that out of the total tendered capacity of $4471 \mathrm{MW}$, almost 47\%, $2094 \mathrm{MW}$ of the proposed tenders were dropped and not actually executed. There has been a tremendous increase in the global demand for power equipment's and supplies due to the increase demand of power and increase in installed capacity. It has been seen that at the global level most of the manufacturing facilities are booked for the next $16 \sim 18$ months also to make matters worse in India due to lack of competition and management there is major reluctance to step into the so called naive market for R\&M in India.

\subsection{O\&M Related Challenges}

The kind of capital and time that is invested in the regular Operation \& Maintenance activities of a power plant directly can be seen as a measure of the efficiency at which the plant is running. Most of the O\& M practises followed by the State owned generation companies in India are weak and not upto the mark. Most of the state owned generating companies do not adhere to the schedule of periodic capital overhaul and annual maintenance leading to deterioration in the condition and performance of the plant. Poor O\&M practises can reduce the expected efficiency levels of a successful R\&M project before the specified extended life of the plant.

Poor O\&M practices impacts the long term performance of plant and leads to its continual deterioration. It is important to have a long term proactively generated procedure for implementation of proper $O \& M$ Practices and procedures. There needs to be periodic review of the operating procedures from the beginning of the project and also identify the loop holes so as prepare an effective O\&M manuals including preventive, capital and breakdown maintenance procedure / guidelines should be formulated.

\subsection{Funding Related Challenges}

Currently, the public sector through loans or grants is funding most of the R\&M projects this is being done through the International Financial Institutions In general the financial demand is likely to be met by the normative structure i.e. $70 \%$ through the loan borrowing from commercial banks or other financial institutions and the remaining $30 \%$ through equity invested by the state. Through expert discussions it has also been highlighted that the non-availability of funds especially with the SEB'S to take up R\&M works is one of the biggest challenges in the Country. As per RBI data the power sector alone utilizes approximately $9.23 \%$ of the Gross bank credit as per data published by RBI on 31st March 2013. Another major challenge with the $R$ \& $M$ projects lies in the poor financial health of the State utilities resulting in the limited debt servicing ability of the utilities. Due to lack of proper planning the available finance is consumed in fire fighting and inappropriately planned schemes rather than being utilized in the useful schemes with long payback and short-term costs, such as R\&M projects. When the R\&M is financed through the Govt schemes generally the lowest capital expenditure option is given first 
priority. The Capital Expenditure for R\&M needs to be managed in such a way as to reduce the short-term increase in power cost from the generating units.

\subsection{Regulatory Challenges}

The existing regulatory framework offers limited incentives to the generating companies against improving the efficiency of the generating unit and for successful implementation of R\&M projects. The benefits obtained on improving the efficiency of power plants were to be fully transferred to the consumer during the tariff revision for that plant based on the Annual tariff setting procedure of the Government of India. Another major challenge lies in the fact that an upfront commitment for the capital costs required and the possible plant performance may be difficult because of the inadequate methodologies adopted for the RLA studies, which cases there intermediate issues and hampers the pace of work. There needs to be a proper analysis comparing the financial cost based tariffs as against the economic pricing of additional power that can be made available by taking up R \& M works. The question still remains that who is the deciding Authority for such issues, the lack of a system makes it even more difficult for investment decisions and decision making procedure becomes extremely slow and non-reliable.

\subsection{Contractual Challenges}

The way the Contract is drafted plays a significant role in the kind of involvement of different stakeholders in a project; it also can have an encouraging or a discouraging impact on the players. It has been observed the risk sharing mechanism is missing in the general Contracts which are being followed by the Generation Companies. During discussions and expert sessions with vendors and consultants, many issues with regards to the Contract were highlighted .The foremost important issue highlighted was the weakly defined scope and many open ended statements in the commercial contract which deliberately shift the risk towards the bidders/Contractors.

It normally takes about 3-4 years between the technical studies (RLA studies, DPR preparation etc) and the commencement of actual R\&M work. This clubbed with inadequate/incomplete technical information provided to the bidders prior to bid restricts the executing party to realistically, model and predict the condition of the existing equipment's before they are opened and inspected which ultimately increase the risk profile of the project.

\subsection{Institutional Related Challenges}

Limited training of utility professionals in the area of planning and execution of R\&M projects, absence of dedicated cell/department at the company level, deployment of the best personnel in the field of new generation capacity and frequent transfers are some of the reasons which have contributed to the limited skills and expertise of the generating company to plan and implement R\&M projects. Interactions with the various stakeholders including suppliers have revealed that after the projects are awarded, the entire risk and responsibility for completion of the project is passed on to the suppliers with limited support by utilities during the implementation process.

One of the major implementation challenges faced by the utilities is that they are unable to schedule timely shutdown for executing R\&M due to grid conditions. Significant energy and peak deficit scenario in most of the states coupled with lack of planning with regard to procurement of power from other sources inhibits shutdown of state owned units for executing R\&M works. In certain cases this is driven by socio-political consideration that results in delay in obtaining the shutdown.

\subsection{Entry Barriers}

The area of $R$ \& $M$ is still on the developing stages and at times the barriers provided the entry level can have a major influence on the development of the potential market. There need to be appropriate levels of barriers and restrictions as these are essential to protect the profitability of existing supplier base as free entry and exit of firm in Industry would affect the profit of firms to a minimal levels and hence, making the industry unattractive. The possible mitigation measures for the above mentioned risks based on the review can be summarized as mentioned in the table below.

Table 1: Summary of the Possible Mitigation Measures

\begin{tabular}{|c|l|l|}
\hline S No & Risk Factor & Possible Mitigation Methods \\
\hline 1. & Supply Risks (Bassanini,2011) & $\begin{array}{l}\text { Supply undertaking (Sponsors/Govt. agency), Collaterals (Until reaches } \\
\text { upto proven level), Reserves prove-up/Assurance, Reserves depletion } \\
\text { protection (Accelerated repayment), Reserve weighting }\end{array}$ \\
\hline 2. & Market Risks (Smith1999) & $\begin{array}{l}\text { Take or pay contracts, Advanced Sales contract, Buy Back Contracts, } \\
\text { Throughput agreements, Minimum Quantity Contracts, Market } \\
\text { preference Contract, Contract monetisation, Merchant financing }\end{array}$ \\
\hline 3. & Foreign Exchange Risk (Lifson 1988) & Forward Contracts, Parallel loans, Barter, Currency Swaps, Commodity \\
\hline
\end{tabular}




\begin{tabular}{|c|c|c|}
\hline & & lending, Commodity lending \\
\hline \multicolumn{3}{|l|}{4.} \\
\hline 5. & $\begin{array}{l}\text { Environmental Risks (Schaufelberger } \\
\text { 2005) }\end{array}$ & $\begin{array}{l}\text { Environmental Management, Rehabilitation Management, Emergency } \\
\text { Response, Environmental Warranty, Environmental Insurances, } \\
\text { Rehabilitation guarantees, Pollution Control Boards }\end{array}$ \\
\hline 6. & Infrastructure Risks (Benjamin2004) & $\begin{array}{l}\text { Infrastructure Contracts, Government Contracts, Pooled Infrastructure, } \\
\text { Transport studies, Free on Board offtakes }\end{array}$ \\
\hline 7. & Political Risks (Tiong 1995,1996$)$ & $\begin{array}{l}\text { Development agreement, Insurance (Export credit agencies)(against } \\
\text { currency inconvertibility, creeping nationalisation, etc), Tax } \\
\text { indemnification ( by sponsors), Offshore payment agent (EOUs), Currency } \\
\text { inconvertibility agreements, Local national participation (Local equity/ } \\
\text { debt), Co-financing (National/Super-national Bodies) }\end{array}$ \\
\hline 8. & Participant Risks (Dailami,2003) & $\begin{array}{l}\text { Cross Collateralization, Deficiency Agreements, Share Pledge, Board } \\
\text { Control }\end{array}$ \\
\hline 9. & Completion Risks (Macmillan,2000) & $\begin{array}{l}\text { Performance bond, Maintenance bond, Completion undertaking, Overrun } \\
\text { standby facilities }\end{array}$ \\
\hline
\end{tabular}

\section{DATA AND METHODOLOGY}

The demand and supply gap of power in the country is increasing day by day and despite the numerous steps taken by the Government this gap is continuously increasing. A developing Country like India which heavily depends on the thermal power plants for its generation of power needs to definitely think of alternatives to increase the generation and reduce this gap. Even though many steps have been taken by the Government to move towards the alternative sources of energy, the major reliance is still on the coal industry

Various studies carried out in the past have highlighted one common concern of the poor and deteriorating efficiencies of the thermal power plants in India. Keeping in mind the various constraints with respect to the green field projects like that of land availability, legal and political concerns and majorly the lack of funds, the only alternative is to look at the other ways of improving efficiencies from the prevailing one. Hence this has generated a need to look into the various risks associated with the implementation of $\mathrm{R} \& \mathrm{M}$ projects in India and how these can be effectively mitigated to increase the efficiency of the thermal power plants in India.

A systematic literature review has been used which attempts to gather all factors that will help to answer the specific research question. It uses systematic methods that are selected with a view to minimizing bias, thus providing reliable findings from which conclusions can be drawn and decisions made. The key characteristics of a systematic review are: (a) a clearly stated set of objectives with an explicit, reproducible methodology; (b) a systematic search that attempts to identify all studies that would meet the eligibility criteria; (c) an assessment of the validity of the findings of the included studies, for example through the assessment of risk of bias; and (d) systematic presentation, and synthesis, of the characteristics and findings of the included studies.

The PRISMA approach for reviewing literature has been followed (figure 1 below). This technique uses a detailed literature review approach to identify and analyze the factors and risks effecting the implementation of Renovation and Modernization projects in India using the databases like google scholar, and web of science, reputed journals and conference proceedings etc. The inclusion criteria's considered were peer-reviewed, empirical, original articles, research and review papers.

In this approach a total of 50 articles have been considered. 5 articles were removed from the 50 initial considered articles. Further the remaining 45 articles were studied and after further screening on the basis of the abstracts and titles 40 articles were taken up for further 5 articles were excluded which were not within the scope of the review or those that did not discuss the risks associated with power sector R \& M. Finally 30 articles were taken up for full review out of which 10 were excluded as these articles were those that were with insufficient statistical information available The remaining 20 articles were then assessed and inclusion criteria applied and were included in this review 
Figure 1: Work Flow Process for PRISMA Technique

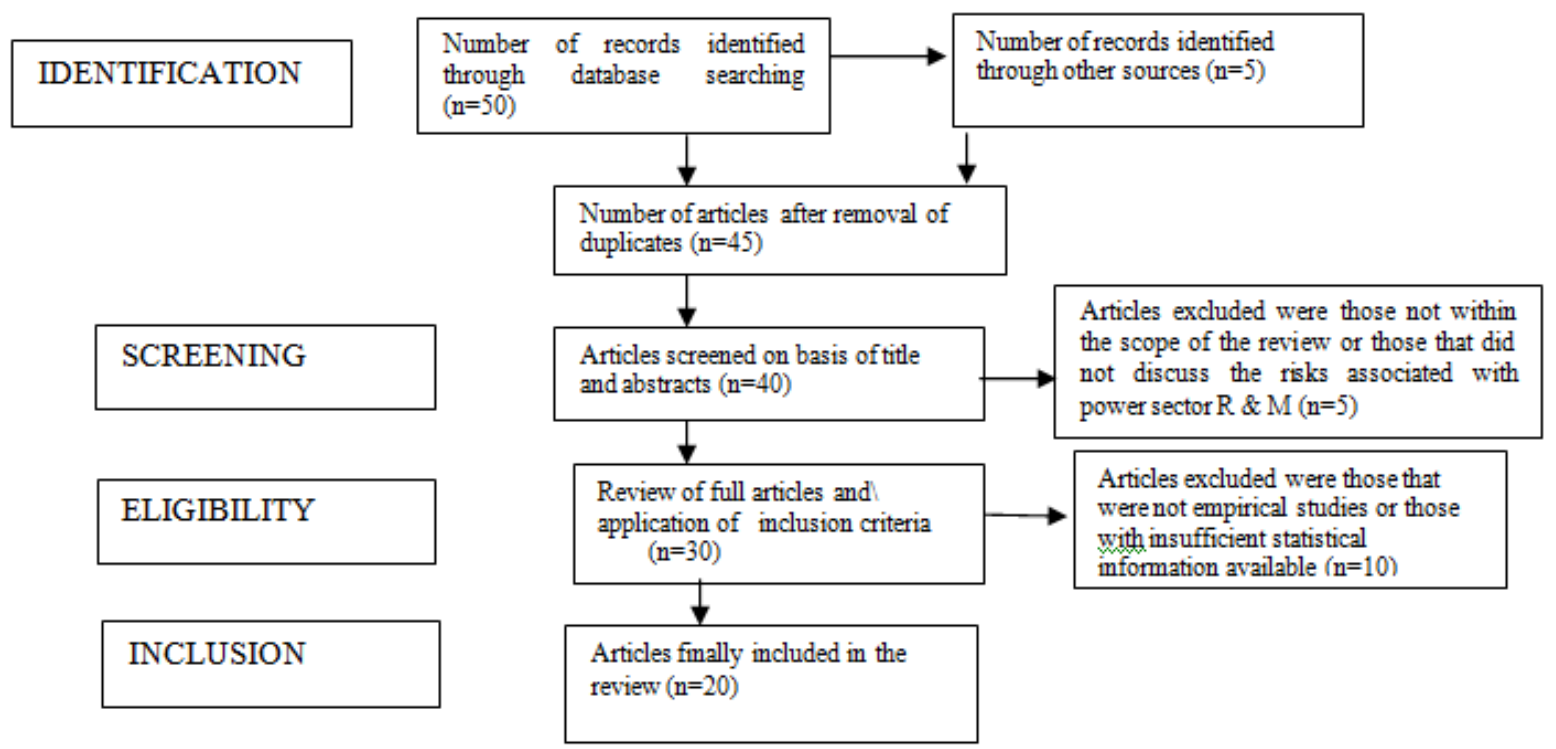

\section{FINDINGS AND DISCUSSIONS}

Based on the extensive literature review as stated above the following risks have been identified as the key challenges to R\& $M$ of the thermal power plants in India.

Table 2: Summary of Risks identified

\begin{tabular}{|c|c|}
\hline S. NO & RISK DESCRIPTION \\
\hline 1. & Market related Risks \\
\hline 1.1 & Award of Contract through nomination and not competitive bidding \\
\hline 1.2 & Non Existence of market for technical consultants \\
\hline 1.3 & Non availability of schedule for sale of power generated. \\
\hline 1.6 & Limited ability of utilities to infuse equity investment in $\mathrm{R} \& \mathrm{M}$ projects \\
\hline 1.7 & Lack of awareness of possible market options \\
\hline 1.8 & Credit exposure to power sector is likely to reach its limit set by most commercial banks \\
\hline 1.9 & Lower vendor participation because of limited competition which leads to higher procurement cost. \\
\hline 1.10 & Rebidding/Reward/Delays in award of R \& M packages/Contract \\
\hline 1.11 & Mismatch (delay) in supply of critical equipment and the shutdown period \\
\hline 2. & Regulatory related Risks \\
\hline 2.1 & Lack of appropriate incentives sharing mechanism for Gencos \\
\hline 2.2 & No bench marks set for $\mathrm{R} \& \mathrm{M}$ works \\
\hline 2.3 & Lack of Government support and incentives \\
\hline 3. & Funding Risk \\
\hline 3.1 & Non availability of funds with utilities for regular $\mathrm{O} \& \mathrm{M}$ procedures \\
\hline 3.2 & Non availability of funds with utilities to take up R \& M projects \\
\hline 3.3 & Credit limit for power sector reaching limits with commercial banks \\
\hline 3.4 & Focus only on technical criteria with limited focus on financial \& economic concerns \\
\hline 3.5 & Lack of confidence of financers on R \& M due to limited success stories in the Country. \\
\hline 4. & Planning Risks \\
\hline 4.1 & Inadequate assessment for R \& M Works and scope of work \\
\hline
\end{tabular}




\begin{tabular}{|c|l|}
\hline $\mathbf{4 . 2}$ & Poorly defined objectives \\
\hline $\mathbf{4 . 3}$ & $\begin{array}{l}\text { Lack of past operating \& performance data with the utility which makes it difficult to identify the actual } \\
\text { improvement areas. }\end{array}$ \\
\hline $\mathbf{4 . 4}$ & $\begin{array}{l}\text { Incomplete studies carried out and the studies carried out majorly focus on only the major components of the } \\
\text { plant }\end{array}$ \\
\hline $\mathbf{4 . 5}$ & Lack of energy Audits \\
\hline $\mathbf{5}$ & Contractual Risks \\
\hline $\mathbf{5 . 1}$ & Unfair and misbalanced risk and reward system between the utilities and contractors \\
\hline $\mathbf{5 . 2}$ & Delays in bid evaluations and award of work \\
\hline $\mathbf{5 . 3}$ & Inappropriate packaging strategy for works \\
\hline $\mathbf{5 . 4}$ & Inappropriate contractual conditions for delay in works and changes in scope of work \\
\hline $\mathbf{5 . 5}$ & Improper contractual conditions for the execution of R \& M works. \\
\hline $\mathbf{5 . 6}$ & Poor dispute resolution mechanism \\
\hline $\mathbf{6 .}$ & Management Risks \\
\hline $\mathbf{6 . 1}$ & Limited project appraisal skills \\
\hline $\mathbf{6 . 2}$ & Inadequate exposure of the utility professionals in the area of planning \& execution of R \& M \\
\hline $\mathbf{6 . 3}$ & Adequate personnel not dedicated to the R \& M Activity \\
\hline $\mathbf{6 . 4}$ & People working in R \& M Projects get transferred to other departments in middle of the project. \\
\hline $\mathbf{6 . 5}$ & Lack of Authority amongst the officials involved. \\
\hline $\mathbf{6 . 6}$ & Lack of decision making by the utility \\
\hline $\mathbf{6 . 7}$ & Lack of long term generation plan and awareness of available market options \\
\hline $\mathbf{6 . 8}$ & Reactive approach for identification of plants for taking up R \& M \\
\hline 7. & Institutional Risks \\
\hline $\mathbf{7 . 1}$ & Limited capacity and capability of state utilities in undertaking R \& M projects \\
\hline $\mathbf{7 . 2}$ & Poor implementation support from utilities while executing R \& M projects \\
\hline $\mathbf{7 . 3}$ & Delay in obtaining unit shutdown for undertaking technical studies \\
\hline
\end{tabular}

\section{REFERENCES}

1. Ahluwalia, Montek Singh (2011), "Prospects and Policy Challenges in the Twelfth Plan", www.planningcommission.nic.in/aboutus/speech/spemsa/spe_21052011.pdf.

2. Bagchi, Amaresh (2007), "Role of Planning and the Planing Commission in the New Indian Economy; Case for a Review", Economic \& Political Weekly, Vol.42, No. 44 (Nov. 3-9, 2007), pp. 92-100.

3. Batra, R K and S K Chand (2011), “India's coal reserves are vastly overstated: is anyone listening” The Energy and Resources Institute, New Delhi.

4. Banker, R.D., A. Charnes and W. W. Cooper, 1984, Some models for estimating technical and scale efficiencies in data envelopment analysis. Management Science 30:1078-1092.

5. Barros, C.P. and N.Peypoch, 2008, Technical efficiency of thermoelectric power plants. Energy Economics 30: $3118-3127$.

6. CEA, 2005. Technical Standard on Operation Norms for Coal/Lignite Fired Thermal Power Stations.Central Electricity Authority, Government of India.

7. CERC, 2000a. Availability Based Tariff, Petition No.2/1999. Central Electricity Regulatory Commission.

8. CERC, 2000b. Operational Norms for Thermal Generation, Petition No. 4/2000, Central Electricity Regulatory Commission. 〈http://〉cercind.gov.in/2612/Order\%20Final.pdf

9. CERC, 2003. Operational norms for thermal generation, Petition No. 4/2000, Central Electricity Regulatory Commission. 〈http:// www.cercind.gov.in/280203/4-00.pdf $\rangle$.

10. Chikkatur, Ananth P (2008), “Coal Initiative Reports: A Resource and Technology Assessment of Coal Utilization in India”, Pew Center on Global Climate Change.

11. Chikkatur, Ananth P. et al, (2009), "Sustainable development of the Indian coal sector", Energy 34 (2009), pp. $942-953$.

12. CEA, 2013,Study Report on developing Markets for Implementation of R\&M Schemes in Thermal Power Stations in India, India: Coal Fired Generation Rehabilitation Project

13. Chand, S.K., Sarkar, S.K., 2006. Demystifying Coal Security. Economic Times, 14 April.

14. Chikkatur, A., 2005. Making the best use of India's coal resources. Economic and Political Weekly 40, 5457-5461. 
15. Central ElectricityAuthority,2006. All India Electricity Statistics. General Review, 2004-2005. Central Electricity Authority, Ministry of Power, Government of India. Available online /http://www.cea.nic.in/s.

16. Central ElectricityAuthority,2008a .17th Electric Power Survey,2007.Central Electricity Authority, Ministry of Power, Government of India.

17. Central Electricity Authority, 2008b. Thermal Performance Review,2007-2008. Central Electricity Authority, Ministry of Power, Government of India .Avail-able online /http://www.cea.nic.in/S.

18. Central ElectricityAuthority,2009a .All India Electricity Statistics. General Review, 2009. Central Electricity Authority, Ministry of Power, Government of India.

19. Dadwal, Shebonti Ray, (2012) “India's Overseas Assets: do they contribute to energy security”, Strategic Analysis, vol. 36, issue. 1

20. Deo Sharma, S.C., 2004. Coal-fired power plant heat rate and efficiency improvement in India. In: Workshop on Near-Term Options to Reduce $\mathrm{CO} 2$ Emissions from the Electric Power Generation Sector in APEC Economies, Asia Pacific Economic Cooperation (APEC), Queensland, Australia.

21. Dubash, N.K. (Ed.), 2002. Power Politics: Equity and Environment in Electricity Reforms. World Resources Institute, Washington, DC.

22. Dubash, N.K., Rajan, S.C., 2001. Power politics: process of power sector reforms in India.Economic and Political Weekly 36, 3367-3390.

23. Dubash, N.K., Singh, D., 2005. Alternating currents: introduction to an international review of electricity restructuring. Economic and Political Weekly 40, 5242-5248.

24. Farrell, M.J., 1957, The measurement of productive efficiency. Journal of royal statistical society 120:7-24.

25. Halder, Dulai (2012), "Overseas investment in Upstream oil and gas: rational, policy, current situation and assessment of strategy", conference presentation, ONGC Videsh Limited, 23May 2012.

26. H. Robinson, P. Carrillo, C.J. Anumba and M. Patel, Governance \& Knowledge Management for Public-Private Partnerships, WileyBlackwell, 2010

27. Jagadeesh, A. (2000), "Wind energy development in Tamil Nadu and Andhra Pradesh, India Institutional dynamics and barriers - A case study", Energy Policy 28 (2000), pp. 157-168.

28. Joseph, Kelli (2010), “The politics of power: electricity reform in India”, Energy Policy 38 (2010), pp. 503-511.

29. J.A. Walewski, International project risk assessment, Dissertation for the degree of Doctor of Philosophy, The University of Texas at Austin, 2005.

30. Kalam, Abdul (2011), former President of India, in address during 21st SMIRT Conference, www.dae.gov.in/press/pr071111.pdf.

31. Kumar, Shukla, Umesh (2011) \& Ashok Thampy, "Analysis of competition and market power in the wholesale electricity market in India," Energy Policy 39 (2011), pp. 2699-2710.

32. L.Y. Shen, A. Platten and X.P. Deng, Role of public private partnerships to manage risks in public sector projects in Hong Kong, International Journal of Project Management, 24(7), (2006), 587-594.

33. Madan, Tanvi (2006). The Brookings Foreign Policy Studies Energy Security Series: India, Washington, DC.

34. Mathew, Jose (2003), "Development Policies of India with Special Reference to New Economic Policy", Mahatma Gandhi University, Kerala.

35. Mathur, Neerja (2010) "Overview of Indian power sector" presentation at Joint IEA-India Workshop on Industrial Energy Efficiency, New Delhi, 27 January 2010.

36. Mathur, Neerja (2011) "Indian Power Sector - An Overview" presentation at Joint IEA-India Workshop on High Efficiency, Low Emission Coal Technology, New Delhi, 29 November 2011.

37. M.H. Sobhiyah, M.R. Bemanian and Y.K. Kashtiban, Increasing VFM in PPP power station projects- Case study: Rudeshur gas turbine power station, International Journal of Project Management, 27(5), (2007), 512-521

38. Pachauri, P K (2005), “Securing India's Energy Future”, The Indian Express, 4 August.

39. R.J. Sawant, Infrastructure Investing: Managing risks \& rewards for pensions, insurance companies \& endowments, John Wiley \& Sons, Inc, 2010.

40. Tavanir, Energy Planning Office Report, Energy Balance Sheets Between1996-2006, Available from Power Ministry library and information centre, 2007. 